\title{
Activity Pattern and Food Habits of Grizzled Giant Squirrel (Ratufa macroura) in Srivilliputhur Grizzled Squirrel Wildlife Sanctuary, Tamil Nadu, Southern India
}

\author{
Golusu Babu Rao ${ }^{1,2}$ *, Rajarathnavel Nagarajan ${ }^{1}$, Murali Saravanan ${ }^{1}$, \\ Nagarajan Baskaran ${ }^{1}$ \\ ${ }^{1}$ A.V.C. College (Autonomous) PG and Research Department of Zoology and Division of Wildlife \\ Biology, Mannampandal - 609 305, Mayiladuthurai, India \\ 2. Care Earth Trust, H.no-3 $6^{\text {th }}$ Street, Thillaiganaga Nagar, Chennai, Tamil Nadu, India.-600 061 \\ Tel: 9994514918 \\ *E-mail address:rao.3in@gmail.com
}

\begin{abstract}
Activity pattern and food habits of Grizzled Giant Squirrel were investigated in Srivilliputhur Grizzled Giant Squirrel Wildlife Sanctuary from December 2011 to March 2012. Focal animal sampling method was used to record the activity pattern and food habits. Sampling was done in three different habitats viz., Private land, Reserve forest and Temple land. Feeding was the dominant activity accounting for $35.4 \%$ of the activity period. Bimodal feeding pattern was observed in Squirrels, the observations were made from early morning hours to till (0600-1800) late evening hours. The Squirrels feed upon 23 plant species; among them 11 were trees species, 10 climbers and 2 shrubs. Seven types of plant parts were used by Squirrels. Leaf consumption was high (38\%) followed by fruit (24\%). The high consumption of leaves was due to easy availability of leaves and limited availability of other plant parts. Squirrel's invasion into Private Land and Temple Land was observed which can be attributed to abundance and easy availability of food plants, canopy continuity and less predatory pressure.
\end{abstract}

Keywords: Activity pattern; Food habit; GGS; Habitat; Plant parts

\section{INTRODUCTION}

The genus Ratufa consists of four species- Ratufa affinis Cream-coloured Giant Squirrel, restricted to Malayan forest, R. bicolor Black Giant Squirrel found in Malayan and North Eastern region of India, $R$. indica Indian Giant Squirrel restricted to India and $R$. macroura Grizzled Giant Squirrel endemic to India and Sri Lanka (Prater, 1980). Three sub species of $R$. macroura have been identified. Ratufa macroura dandolena is found in Tamil Nadu and Sri Lanka while Ratufa macroura macroura and Ratufa macroura melanochra are found only in Sri Lanka (Ellermen, 1961). Grizzled Giant Squirrel (GGS) is an arboreal Squirrel, largely confined to riverine habitats in the rain shadow regions of Southern India, primarily in the Western Ghats. Recently it has been reported from two sites in the Eastern 
Ghats (Karthikeyan et al., 1992; Kumara \& Singh 2006; Baskaran et al., 2011; Babu \& Kalai Mani, 2014). In its range in south India, GGS shares its habitat with Indian Giant Squirrel $(R$. indica) in the Palani hills (Joshua, 1992). The population of GGS has been reduced to about $30 \%$ of its early distribution in the last 25 years due to habitat loss and hunting (Joshua and Johnsingh, 1992, 1994; Molur et al., 2005). Now the total estimated population of GGS is less than 500 individuals according to the IUCN (2010) estimate. Senbakathoppu valley of the Grizzled Giant Squirrel sanctuary has more than $50 \%$ of GGS population (Vanitharani et al., 2011). GGS is presently listed as near threatened species in the IUCN red list (IUCN Red List 2013) and is placed in Appendix II of CITES to regulate its international trade and is also included under Schedule I of the Wildlife Protection Act (1972).

Apart from the study by Joshua (1992) no other study exists on the species. Joshua's study was limited to the reserve forest and he does not mention the presence of species in the temple and private lands outside the reserve. For the first time in this paper we report the activity pattern and food habits of the species in habitats newly occupied by the species outside the reserve forest and draw inference for the presence of this species outside its original range. Such a study was essential as it draws our attention towards protection of species outside protected areas. Moreover, GGS is an endangered species and deserves the attention of conservationists (Paulraj, 1991).

\section{STUDY AREA}

The study was conducted from December 2011-March 2012 at Senbakathoppu valley in Srivilliputhur Grizzled Giant Squirrel Wildlife Sanctuary in Tamil Nadu, Southern India. This Sanctuary was created in 1989, and covers an area of $480 \mathrm{~km}^{2}$. The sanctuary spreads across Virudhunagar and Madurai districts and lies between $9^{\circ} 32^{\prime} 47.30 " \mathrm{~N}$ Latitude and $77^{\circ} 33^{\prime} 18.95^{\prime \prime E}$ Longitude. This area harbors diverse vegetation types ranging from dry deciduous forest and thorn scrub jungle. Dry deciduous forests is composed of tree species like Albizia lebbeck, Albizia amara, Acacia spp, Terminalia spp, Tamarindus indica, Feronia elephantum etc., the dominant plant species in the Dry deciduous forest are Albiza lebbeck and Terminalia bellirica, and the species dominant in Scrub jungle are Acacia leucocephala and Albizia amaraa. While two temples are present these temples are frequently visited by number of pilgrims every day. An average thousand people come and visit these area every month.

The core study area within the Sanctuary was in Senbakathoppu valley. This site contains Private land, Reserve forest and Temple land, all lying around the riverine habitat of Senbakathoppu valley. The Reserve forest is dominated by Tamarindus indica. The Temple land contains a mix of planted species (Tamarind, Mango and Amla) and with reserve forest species. This pocket of land has been left unmanaged for several years and hence there is dense undergrowth and many species of climbers. The Private land is very well managed and there is hardly any undergrowth and climber species. The planted species in the Private land include Mangifera indica, Tamarindus indica, Coccus nucifera, Adansonia digitata, Manilkara zapota, Psidium spp, Citrus spp, Pithecellobium dulce and Terminalia arjuna. 


\section{MATERIALS AND METHODS}

\section{Activity Pattern}

The diurnal activity pattern of GGS was studied using focal animal sampling method (Altmann, 1974). Two individuals were selected from each habitat (one adult male and adult female) for data collection throughout the study period. However, in the Temple land 2 males and 2 females were observed. So, in total, 4 males and 4 females were followed to collect data on activity pattern and food habit. Individuals could be easily differentiated in the field by their specific coat colour and other morphological characters. Data was collected from 0600 - 01800 for 10 minutes at a 5 minute interval. Hence $12 \mathrm{~h}$ observations were recorded/day/individual. The activities were recorded using 7'x50" binocular. The roosting places of the targeted individual were identified the previous day to continue the fieldwork on the following subsequent day. Squirrels were observed from $10 \mathrm{~m}$ distance by hiding in one place. To avoid close contact with animal care was taken that observer was not seen by the study animal. Ambient temperature was recorded by using thermometer for every $10 \mathrm{~m}$ observation. Local weather condition (sunny, cloudy and rainy) was recorded during the observation period. Plant species used, the plant part consumed, time spent for consumption was also noted down.

\section{Food preference}

To investigate the preference of food plant species Jacobs' index of preference (D) was calculated using the formula

$$
D=\frac{r-p}{r+p}-2 r p
$$

Where $\mathbf{r}$ is the proportion of a particular category in the diet and $\mathbf{p}$ is the proportion of that category in the population. Proportions were calculated in terms of relative density of plant species. The index varies from 0 to 1 in which 0 representing no preference and 1 absolute preference for that category, i.e., no other category was consumed.

\section{RESULTS}

\section{Activity Pattern}

The activity pattern of GGS across the day from December 2011 to March 2012 in three different habitats is given in (Table 1). Totally, eight different behaviors were observed viz., feeding, moving, exploring, grooming, chasing, freezing, resting and others. The "others" category includes playing, calling, urinating, defecation, nest arrangement, mating, cleaning, hanging, yawning, etc. GGS spent maximum time on feeding and the time spent on feeding in different habitats was $26.1 \%, 36.4 \%$ and $35.4 \%$ in Private land, Reserve forest, and Temple land respectively. There were two peaks in the mode of feeding in all the habitats of which the first peak was in the morning and another was at the end of the day. The second dominant activity was resting in all the habitats. The percentage of time spent on resting was $35.9 \%$ in Private land, $28.8 \%$ in Reserve forest and $30.5 \%$ in Temple land. Resting behavior was 
observed more during the midday hours. The time spent on exploring which included vigilance comprised of $7.6 \%$ in Private land, $8.8 \%$ in Reserve Forest and $9.1 \%$ in Temple land. The other activity 'moving' was associated with disturbance and food location and the time spent on moving by squirrels was $19.3 \%, 14.1 \%$ and $15.5 \%$ in Private land, Reserve forest and Temple land respectively. The time spent on grooming was higher in females, while the time spent on chasing was higher in males. Auto and allogrooming is common in Squirrels. Allogrooming was noticed in breeding pairs. Chasing was commonly seen in males during mating and also at times of territorial defense. The time spent on freezing was relatively higher in females in almost all habitats. The time spent on other activities fluctuated widely between sexes and among the habitats.

\section{Food habits}

GGS fed on 23 different plant species during the study period. $48 \%$ were trees, $43 \%$ climbers and 9\% shrubs (Fig 1). Nineteen plant species were used in Temple land, 6 species in Reserve forest and 5 Species in Private land (Table 2). From the 23 plant species, seven plant parts were utilized by GGS. Leaves were most frequently consumed (38\%), followed by fruit $(24 \%)$, bark (15\%), flower (12\%), Pith (6\%), flower buds (3\%) and seeds (3\%) (Fig 2). Leaves of Mangifera indica and Tamarindus indica were most frequently used. The squirrels used bark from 5 different plant species viz., Mallotus philippensis, Mangifera indica, Phyllanthus emblica, Tamarindus indica and Terminalia arjuna. Bark was consumed chiefly from Tamarindus indica and Mallotus philippensis. Among fruits, Tamarindus indica and Mangifera indica were mostly consumed. Squirrels fed on flowers mainly from Albizia lebbeck and Mangifera indica. Pith consumption was more in Mangifera indica and Tinospora cordifolia. Flower buds of Adansonia digitata and seeds of Ziziphus oenoplia were the other food sources. Overall Tamarindus indica and Mangifera indica were the dominant food plant species of GGS. GGS consumed five plant parts of Mangifera indica (flowers, fruits, leaves, bark and pith), 3 plant parts (fruits, leaves and bark) of Tamarindus indica and Kelinandara (flowers, fruits and leaves) (Fig 3). The availability of different food plants and parts used in different months in three habitats was diverse (Table 3). The number of food plants availability is more in Temple land in all the months compared to other two areas. Food plants utilization and their consumed food part number increased from December to March. Consumption of leaves were very regular in all months this because it was most readily available of the plant part.

\section{DISCUSSION}

\section{Activity Pattern}

In general, time spent on feeding was highest, both in males and females compared to all other activities. Warm blooded animals have to constantly feed to maintain body temperature and to supply necessary oxygen for regular activities. Females relatively spend more time on feeding than males, which is due to the higher reproductive cost of females (Joshua, 1992). Some studies showed that seasonal changes in activity pattern of tree squirrels results from resting and sleeping to conserve the energy while on the gain energy (Tonkin, 1983; Reynolds, 1985; Gurnell, 1987; Wauter and Dhondt, 1987). The bimodal feeding pattern was observed similar to what was observed during the previous study (Joshua, 1992). 
Similarly, bimodal feeding behavior has been observed in Malabar Giant Squirrel at Thellikkal region of Parambikulam Wildlife Sanctuary (Ramachandra, 1988). The bimodal feeding pattern exhibited by the squirrel can be attributed to the higher ambient temperature during the mid-day hours. With increasing ambient temperature the species reduces the time spent on feeding and rests during mid-day hours and again gradually increases the feeding time during the evening hours resulting in a bimodal feeding pattern (Baskaran et al., 2011). Squirrels are very particular to maintain body temperature as was observed In Sitamata Wildlife Sanctuary, Rajasthan, the nocturnal flying Squirrel (Petaurista philippensis) was observed resting on tree branches during the day time to avoid hot temperature in tree holes (Bhatnagar et al., 2010).

The time spent on moving was relatively higher in Private land than other habitats. This could be attributed to resource availability and dense canopy in private land compared to other two habitats. Canopy connectivity plays a major role in arboreal animals as it directly influences the activity budget of animals. Good canopy continuity provides protection from predators and an easy escape route (Ramachandran, 1992). Predators like Black kite and Crested Serpent Eagle were commonly observed in the study area but they were not recorded feeding or chasing squirrels. Freezing behavior was noticed in females to avoid disturbance, generally this behavior was observed for five to ten minutes, but Joshua (1992) recorded this behavior continuously for up to 30 minutes. The time spent on resting gradually increased in both sexes from the morning and it attained peak during middle of the day when the environment was hot in all three habitats, this behavior is similar to the other studies reported for the same species (Joshua, 1992) and for Indian giant squirrel (Baskaran et al., 2011). Resting behavior was observed more in this study area. Apart from the temperature there is another factor that may also influence resting behavior. This resting might be attributed to continuous human disturbance in the study area this disturbance caused by increased movement of pilgrims in the study area. Cattle grazing is also another disturbance responsible factor for squirrel resting behavior.

\section{Food plants}

In the present study, totally 23 plant species were recorded to be consumed by GGS. In all three habitats Tamarindus indica was the major food source followed by Mangifera indica. The high consumption of Magifera indica and Tamarindus indica is a reflection of the overall abundance of these two species in the study site. In the same area Joshua (1992) recorded 37 different plant species in the diet of Grizzled Giant Squirrel. The observed difference in number of plant species consumed is due to duration of the study and spatial location where observations were carried out. In the present study GGS consumed 7 plant parts from 23 species of plants. Leaves were the most dominant food item followed by bark, fruit, flower, pith, seeds and flower buds. However, Joshua (1992) reported seeds and barks as the major food item, constituting $61 \%$ of GGS diet. Squirrels are very particular in food part selection. Kuo and Lee (2003) recorded 79 species-specific parts from 30 plant species in the diet of Flying Squirrel (Petauristia philippensis). Nandini and Parthasarathy (2008) recorded 4 plant parts of 9 plant species in Giant Flying Squirrel's diet. Koli et al., (2013), reported 8 parts from 20 plant species in diet of Giant Flying Squirrel. In our study we observed that leaves were the dominant part of Squirrel's diet. The higher leaf consumption is due to less availability of other food parts during the study period. Squirrels consumed sprouting leaves rather than mature leaves as young leaves are less fibrous and more nutritious than mature leaves (Coley, 1983). Moreover digestion inhibiting substances such as cellulose, tannins and 
lignin are less in young leaves (Krishnamani, 1994). Bark and seeds also formed important part of GGS's diet in the study area. Joshua (1992) emphasized that seeds and bark are generally available almost all round the year and therefore they form the bulk of the squirrel's diet. Malabar Giant Squirrel is also reported to feed on seeds and bark which are reported to have high calorific content (Borges, 1989). Bark feeding is very common in rodents when there was shortage of other food species (Joshua, 1992). Flowers and fruits are however seasonal and are consumed intensively when available. Their restricted seasonal availability results in lower contribution to the annual food even though their seasonal contribution is extremely high. Pith was consumed more in Mangifera indica as it rich in water content and is nutritious. According to Bhatnagar et al., (2010) feeding on pith fulfills the requirement of water during summer season. Nutritional analysis of the food items will help us throw more light on the food preferences of GGS.

\section{Reason for Squirrel invasion into private land}

Private land (farm land) and Temple land both are plantation areas and nearly 100 individuals were recorded in these two habitats. The possible reasons for the recent invasion of Grizzled Giant Squirrel into the farmland (Private land) and Temple land were investigated by the comparing food plant species composition, food preference of squirrel and percentage of time spent on different activities in three habitats viz., Private Land, Reserve forest, and Temple land (Table 4). Among these the Food Plant Richness in different habitats was 5, 3, and 9 for Private Land, Reserve forest and Temple land respectively and the food species diversity was $1.176,0.263$ and 0.988 for the above three different habitats. The squirrels managed to feed only on three species of plants in their native habitat i.e. Reserve Forest and the diversity of these plants was poor $\left(H^{\prime}=0.263\right)$. In addition, in this habitat they spent highest amount of time (36.4\%) on feeding and also on exploration $(8.8 \%)$. On the other hand, the squirrel fed on wide varieties of food plants in Temple land where the plant food diversity was $0.988\left(H^{\prime}=0.988\right)$ which was however lower than that of Private Land. In Private Land the diversity was highest $\left(H^{\prime}=1.176\right)$ although the number of species was lower than that of Temple land. In all the three habitats the squirrel fed extensively on Tamarind trees. The preference for Tamarind was positive in Reserve Forest and Temple Land but negative in Private Land where the squirrel fed extensively on mango trees and showed strong preference $\left(D^{\prime}=0.291\right)$. The preference for mango was positive in Temple land as well. Differences in food availability and quality among habitats may influence the activity and foraging behavior of squirrels (Wauters et al., 1992). The present study clearly indicates that squirrels spend more time on feeding in Reserve forest than other two habitats and further the availability of food plants in Reserve forest was found to be low. Farm lands had plenty of food resources and in each season Squirrels got to an opportunity to feed upon different varieties of food. This could be one of the reasons for Squirrel invasion into farm lands from the Reserve Forest. Squirrels generally avoid the areas with low quality of food sources and concentrate their activities in habitats with more abundant food resources (Lurz et al., 2000). Some studies in other Squirrels show that flying squirrels of Asia are predominantly folivorous with diet dependent on the habitat where they are found (Muul and Liat 1978; Ando et al., 1985; Lee et al., 1986; Kawamichi, 1997; Kuo and Lee 2003; Nandini \& Parthasarathy 2008). Selection of food seems to be related to nutritional content of the feed (Dial, 2003). It is suggested that in Private Land and Temple land by feeding on mango and other food tress the squirrel would have achieved the daily intake within short period of time and hence had to spent lowest amount time on feeding in these habitats when compared to 
Reserve Forest. The Temple Land seems to be a Reserve Forest with dense growth of Mango and Tamarind tress, apart from shrub and climber species in this area. The dense growth of these plant species provide easy movement and resource accessibility. The dense canopy cover could provide protection and prevent detection by predatory birds. Other inter-specific species Three striped Palm Squirrel (Funambulus palmarum) and Bonnet macaque (Macaca radiata) were seen in study area but there was no competition observed between these three species. The availability food plants and food parts preference in different months in Reserve forest was very low compared to other two habitats. This could be the possible reason for the squirrel to invade to Private Land and Temple Land. Squirrels restricted their movement in Reserve forest probably because of low canopy continuity and availability of limited resource. As a result they tend to spend lesser amount of time on other activities.

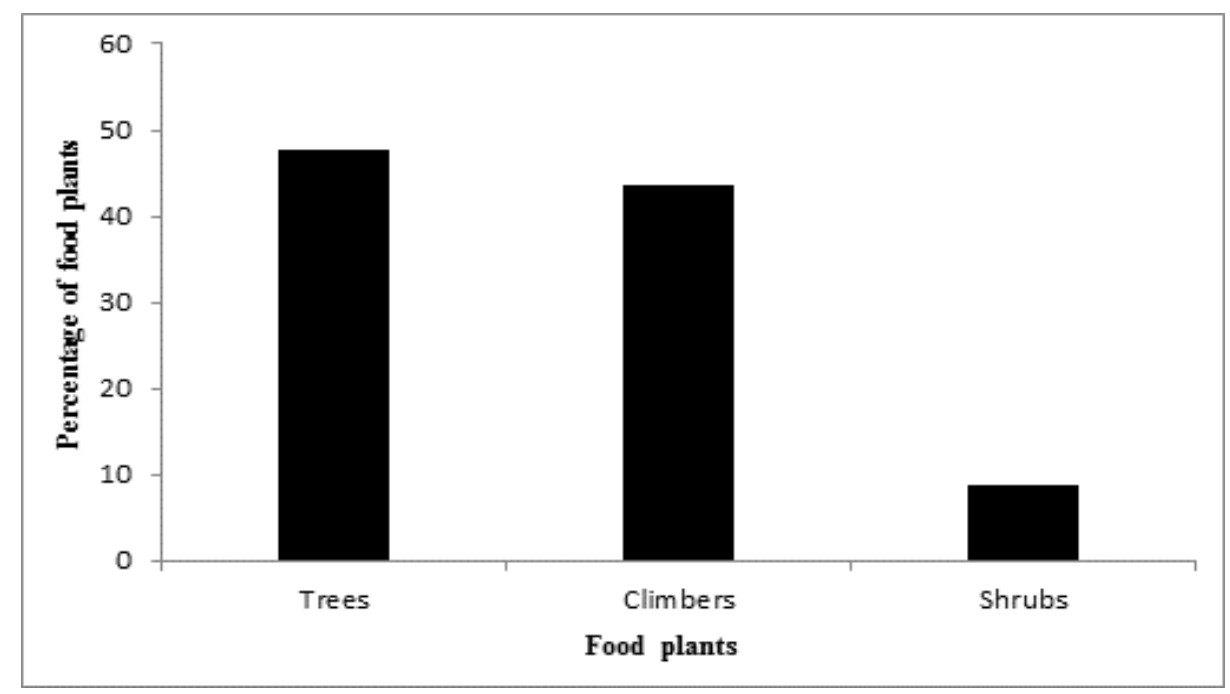

Figure 1. Percentage of different food plants eaten by GGS in Senbakathoppu valley during the study period from December 2011- March 2012.

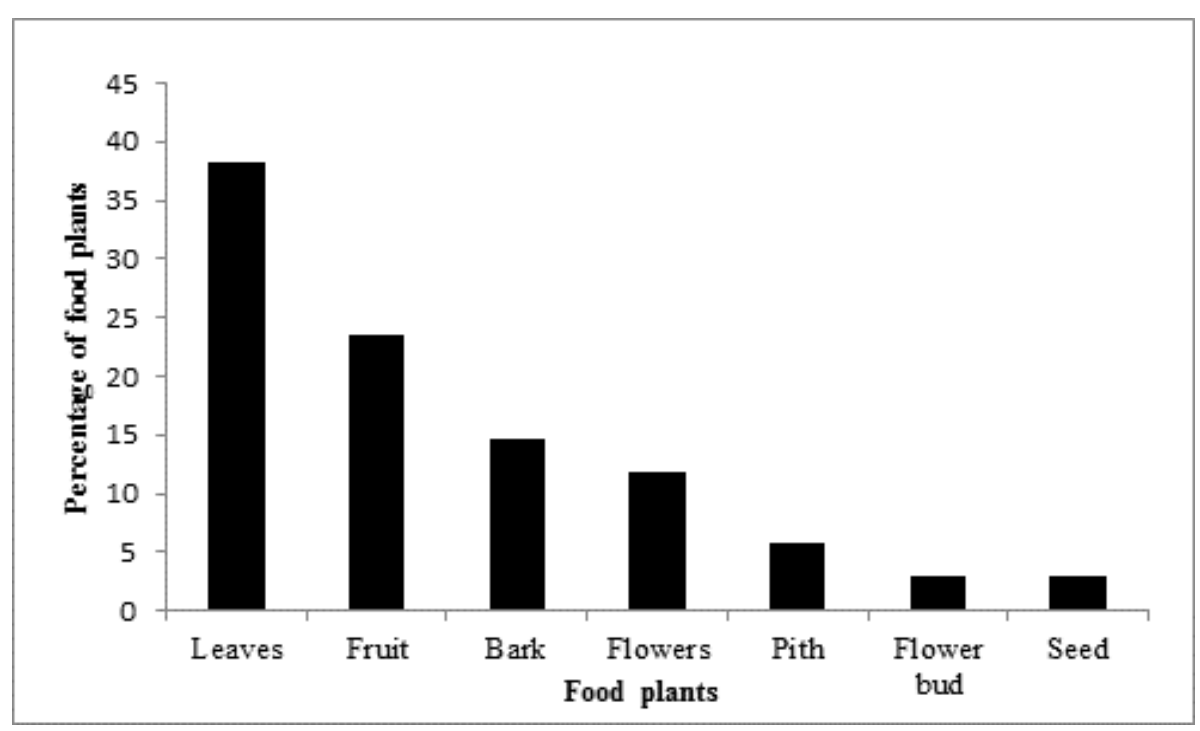

Figure 2. Percentage of different plant parts consumed by GGS in Senbakathoppu valley during the study period from December 2011- March 2012. 


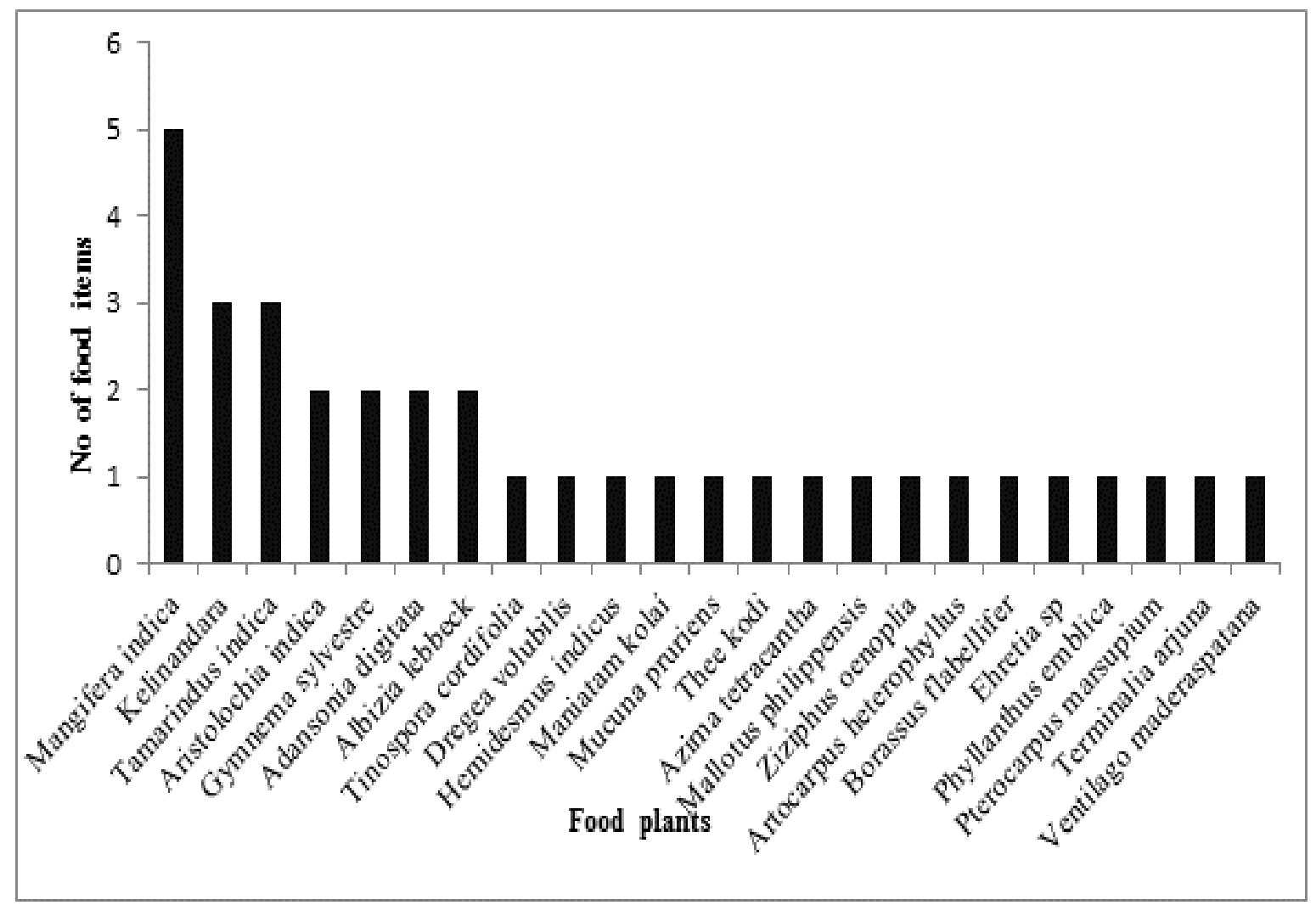

Figure 3. Number of parts eaten as a food item in different species of plants by GGS in Senbakathoppu valley during the study period from December 2011- march 2012.

Table 1. Percentage of different activities of GGS in three different habitats in Senbakathoppu valley during the study period from December 2011-March 2012.

\begin{tabular}{|c|c|c|c|}
\hline Activity & Private land (\%) & Reserve forest (\%) & Temple land (\%) \\
\hline Feeding & 26.1 & 36.4 & 35.4 \\
\hline Moving & 19.3 & 14.1 & 15.5 \\
\hline Exploring & 7.6 & 8.8 & 9.1 \\
\hline Grooming & 4.4 & 3.5 & 3.8 \\
\hline Chasing & 1.1 & 1 & 0.6 \\
\hline Freezing & 2.1 & 2.5 & 2.3 \\
\hline Resting & 35.9 & 28.8 & 30.5 \\
\hline Others & 3.5 & 5 & 3.5 \\
\hline
\end{tabular}


Table 2. Details of food plants of GGS, plants parts eaten in Senbakathoppu valley during the study period from December 2011-March 2012.

\begin{tabular}{|c|c|c|c|c|}
\hline S.no & Food specie & Life form & Habitat & Parts eaten \\
\hline 1 & Aristolochia indica & Climber & TM & $\mathrm{L}$ \\
\hline 2 & Tinospora cordifolia & Climber & $\mathrm{TM}$ & $P$ \\
\hline 3 & Dregea volubilis & Climber & $\mathrm{TM}$ & $\mathrm{L}$ \\
\hline 4 & Gymnema sylvestre & Climber & TM & $\mathrm{L} \& \mathrm{FR}$ \\
\hline 5 & Hemidesmus indicus & Climber & $\mathrm{TM}$ & $\mathrm{L}$ \\
\hline 6 & Kelinandara & Climber & $\mathrm{RF}$ & $\mathrm{L}, \mathrm{FL} \& \mathrm{FR}$ \\
\hline 7 & Maniatam kolai & Climber & $\mathrm{TM}$ & $\mathrm{L}$ \\
\hline 8 & Mucuna pruriens & Climber & TM & $\mathrm{L}$ \\
\hline 9 & Thee kodi & Climber & RF & $\mathrm{L}$ \\
\hline 10 & $\begin{array}{c}\text { Ventilago } \\
\text { maderaspatana }\end{array}$ & Climber & $\mathrm{TM}$ & FR \\
\hline 11 & Azima tetracantha & Shrub & $\mathrm{TM} \& \mathrm{RF}$ & $\mathrm{L}$ \\
\hline 12 & Ziziphus oenoplia & Shrub & $\mathrm{TM}$ & Seed \\
\hline 13 & Mallotus philippensis & Tree & TM & BR \\
\hline 14 & Adansonia digitata & Tree & TM \& PR & FR\&BUD \\
\hline 15 & Albizia lebbeck & Tree & $\mathrm{TM}, \mathrm{PR} \& \mathrm{RF}$ & FL \& FR \\
\hline 16 & Artocarpus heterophyllus & Tree & $\mathrm{TM}$ & FR \\
\hline 17 & Borassus flabellifer & Tree & $\mathrm{TM}$ & FL \\
\hline 18 & Ehretia $s p$ & Tree & $\mathrm{RF}$ & $\mathrm{L}$ \\
\hline 19 & Mangifera indica & Tree & TM \& PR & FL,FR, L, P\& BR \\
\hline 20 & Phyllanthus emblica & Tree & $\mathrm{TM}$ & $\mathrm{BR}$ \\
\hline 21 & Pterocarpus marsupium & Tree & $\mathrm{TM}$ & $\mathrm{L}$ \\
\hline 22 & Tamarindus indica & Tree & TM, PR \& RF & FR, L, BR \& Seed \\
\hline 23 & Terminalia arjuna & Tree & PR & $\mathrm{BR}$ \\
\hline
\end{tabular}

Habitat: TM-Temple Land; RF- Reserve forest; PR-Private Land. Food pats: L-Leaves; P-Pith; FR-Fruit; FL-Flower; BR- Bark.

Table 3. Availability of food plants in different months and parts used in three GGS habitats.

\begin{tabular}{cccc}
\hline Habitat & Month & Food Sp. & Plant parts eaten \\
& December & Tamarindus indica & Fruit, seed \\
& & Terminalia arjuna & Bark \\
Private land & & Adansonia digitata & Flower bud \\
& & Albizia lebbeck & Fruit \\
& Mangifera indica & Pith, Bark \\
& January & Mangifera indica & Leaves, Pith \\
& February & Mansonia digitata & Flower bud \\
& & Tamarindus indica & Pith \\
& March & Terminalia arjuna & Fruit, Seed \\
& & Albizia lebbeck & Bark \\
& & Adansonia digitata & Flower \\
& &
\end{tabular}




\begin{tabular}{|c|c|c|c|}
\hline & & $\begin{array}{l}\text { Mangifera indica } \\
\text { Tamarindus indica } \\
\text { Terminalia arjuna }\end{array}$ & $\begin{array}{c}\text { Fruit, Pith, Flower } \\
\text { Fruit, Seed } \\
\text { Bark }\end{array}$ \\
\hline \multirow[t]{13}{*}{ Reserve forest } & December & Tamarindus indica & Seed \\
\hline & January & Tamarindus indica & Seed, Bark \\
\hline & & Kelinandara & Leaves \\
\hline & February & Tamarindus indica & Leaves, Fruit, Seed, Bark \\
\hline & & Albizia lebbeck & Flower \\
\hline & & Azima tetracantha & Leaves \\
\hline & & Kelinandara & Leaves \\
\hline & March & Tamarindus indica & Leaves, Fruit, Seed, Bark \\
\hline & & Albizia lebbeck & Leaves, Flower \\
\hline & & Azima tetracantha & Leaves \\
\hline & & Kelinandara & Leaves, Flower, Fruit \\
\hline & & Thee kodi & Leaves \\
\hline & & Ehretia sp & Leaves \\
\hline \multirow[t]{32}{*}{ Temple land } & December & Tinospora cordifolia & Pith \\
\hline & & Gymnema sylvestre & Leaves \\
\hline & & Maniatam kolai & Leaves \\
\hline & & Mucuna pruriens & Bark \\
\hline & & Tamarindus indica & Bark, Seed \\
\hline & & Mangifera indica & Pith \\
\hline & January & Mallotus philippensis & Bark \\
\hline & & Tamarindus indica & Leaves, Seed, Bark \\
\hline & & Dregea volubilis & Leaves \\
\hline & & Gymnema sylvestre & Leaves \\
\hline & & Mangifera indica & Leaves \\
\hline & & Maniatam kolai & Leaves \\
\hline & & Mucuna pruriens & Leaves \\
\hline & & Ziziphus oenoplia & Seed \\
\hline & February & Phyllanthus emblica & Bark \\
\hline & & Tamarindus indica & Leaves, Fruit, Seed, Bark \\
\hline & & Artocarpus heterophyllus & Fruit, Leaves \\
\hline & & Azima tetracantha & Leaves \\
\hline & & Dregea volubilis & Leaves \\
\hline & & Gymnema sylvestre & Leaves \\
\hline & & Mangifera indica & Flowers, Leaves, Fruit \\
\hline & & Artocarpus heterophyllus & Fruit \\
\hline & & Ziziphus oenoplia & Seed \\
\hline & & Albizia lebbeck & Seed \\
\hline & March & Borassus flabellifer & flowers \\
\hline & & Tamarindus indica & Fruit, Seed, Bark \\
\hline & & Artocarpus heterophyllus & Fruit \\
\hline & & Albizia lebbeck & Fruit \\
\hline & & Aristolochia indica & Leaves \\
\hline & & Azima tetracantha & Leaves \\
\hline & & Dregea volubilis & Leaves \\
\hline & & Gymnema sylvestre & Leaves, Fruit \\
\hline
\end{tabular}




\begin{tabular}{cc} 
Hemidesmus indicus & Leaves \\
Mangifera indica & Flower, Leaves, Pith, \\
Pterocarpus marsupium & Bark, Fruit \\
Ventilago maderaspatana & Leaves \\
Mallotus philippensis & Fruit \\
Tinospora cordifolia & Bark \\
Ziziphus oenoplia & Pith \\
Aristolochia indica & Seed \\
Adansonia digitata & Fruit \\
\hline
\end{tabular}

Table 4. Percent availability and consumption of food in different plant species, preference index, food species richness, preferred food species richness and food plant diversity of GGS in various habitat.

\begin{tabular}{|c|c|c|c|c|c|c|c|c|c|}
\hline \multirow{2}{*}{ Food plant species } & \multicolumn{3}{|c|}{ Private Land } & \multicolumn{3}{c|}{ Reserve Forest } & \multicolumn{3}{c|}{ Temple Land } \\
\cline { 2 - 11 } & Pop & Used & $\mathbf{D}^{\prime}$ & Pop & Used & $\mathbf{D}^{\prime}$ & Pop & Used & $\mathbf{D}^{\prime}$ \\
\hline Adansonia digitata & 28.6 & 18.7 & -0.269 & -- & -- & -- & 3.5 & 1.3 & -0.468 \\
\hline Albizia lebbeck & 3.6 & 3.4 & -0.026 & 5.1 & 1.6 & -0.535 & 5.3 & 1.7 & -0.525 \\
\hline $\begin{array}{c}\text { Artocarpus } \\
\text { heterophyllus }\end{array}$ & -- & -- & -- & -- & -- & -- & 3.5 & 3.7 & 0.029 \\
\hline Bignonia colais & -- & -- & -- & 10.3 & -- & -1 & -- & -- & -- \\
\hline Borassus flabellifer & -- & -- & -- & -- & -- & -- & 8.8 & 0.3 & -0.939 \\
\hline Ehretia sp & -- & -- & -- & 2.6 & 2.6 & 0 & -- & -- & -- \\
\hline Diospyros calycina & -- & -- & -- & 5.1 & 0 & -1 & -- & -- & -- \\
\hline Feronia elephantum & -- & -- & -- & -- & -- & -- & 8.8 & 0 & -1 \\
\hline Guatteria fragrans & -- & -- & -- & 7.7 & 0 & -1 & -- & -- & -- \\
\hline $\begin{array}{c}\text { Mallotus } \\
\text { philippensis }\end{array}$ & -- & -- & -- & 7.7 & 0 & -1 & 5.3 & 0.5 & -0.834 \\
\hline Mangifera indica & 35.7 & 50.3 & 0.291 & -- & -- & -- & 22.8 & 27.5 & 0.124 \\
\hline Phyllanthus emblica & -- & -- & -- & 5.1 & & -1 & 1.8 & 0.1 & -0.894 \\
\hline $\begin{array}{c}\text { Pterocarpus } \\
\text { marsupium }\end{array}$ & -- & -- & -- & -- & -- & -- & 3.5 & 0.1 & -0.946 \\
\hline Randia sp & -- & -- & -- & 5.1 & & -1 & -- & -- & -- \\
\hline Tamarindus indica & 28.6 & 26.5 & -0.052 & 48.7 & 89.2 & 0.794 & 36.8 & 55.1 & 0.356 \\
\hline Terminalia arjuna & 3.6 & 1.1 & -0.538 & -- & -- & -- & -- & -- & -- \\
\hline Terminalia bellirica & -- & -- & -- & 2.6 & 0 & -1 & -- & -- & -- \\
\hline Food Plant Richness & & 5 & & & 3 & & & 9 & \\
\hline $\begin{array}{c}\text { Preferred Food } \\
\text { Plant Richness }\end{array}$ & & & $\mathbf{1}$ & & & $\mathbf{1}$ & & & $\mathbf{3}$ \\
\hline $\begin{array}{c}\text { Food Species } \\
\text { Diversity }\end{array}$ & & $\mathbf{1 . 1 7 6}$ & & & $\mathbf{0 . 2 6 3}$ & & & $\mathbf{0 . 9 8 8}$ & \\
\hline
\end{tabular}




\section{CONCLUSION}

This study finally concludes that the recent invasion of GGS into farm lands (plantation) is mainly because of plenty of food species availability. Squirrels obtain their daily intake within a short period of time spending less amount of time and also species has less predatory pressure. To understand more about Squirrel Invasion into farm land and their survival in these habitats need future long-term studies on squirrels' feeding pattern in relation to nutritional chemistry of different plant parts with monthly changes are required to understand the selection and preference for particular trees as well as plant parts in their diet respectively.

\section{Acknowledgement}

We are expressing our sincere thanks to Thiru DFO Srivilliputhur Grizzled Giant Squirrel Wildlife Sanctuary for provided permission to carry out this Research. I also thankful to Dr.Patrick david and Dr. Avanthika Baskar for their help in writing manuscript. I very grateful to Dr. Thyiagesan principal of the A.V.C College for his constant support and encouragement throughout the project and also other staff J. Pandiyan, V. Jaykumar, M.Varadarajan, A. Asokan, S. Sandiliyan M. Baskaran A.V.C college department of zoology and Wildlife biology. My special thanks to my classmates B. Naresh, R. Mani raj, D. Mahendar reddy and B. Krishna kumar.

\section{References}

[1] Altmann, J. (1974). Observational study on behaviour: Sampling methods. Behaviour 49: 227- 267.

[2] M. Ando, S. Shiraishi, Uchida, T. A. (1985). Food habits of the Japanese giant flying squirrel, Petaurista leucogenys. Journal of the Faculty of Agriculture, Kyushu University (Japan). 29:189-202.

[3] N. Baskaran, S.K. Srivastava, Desai, A.A. (2011). Some aspects of the ecology of Indian Giant Squirrel (Ratufa indica Erxleben, 1777) in the tropical forests of Mudumalai Wildlife Sanctuary, Southern India and their conservation implications. Journal of Threatened Taxa. 3(7): 1899-1908.

[4] N. Baskaran, K. Senthilkumar, Saravanan, M. (2011). A new site record of the Grizzled Giant Squirrel (Ratufa macroura) (Pennant, 1769) in the Hosur forest division, Eastern Ghats, India and its conservation significance. Journal of Threatened Taxa. 3(6):18371841 .

[5] C. Bhatnagar, S.K. Satish, Koli, V.K. (2010). High day temperature and sleep out behavior of Elliot's Giant flying Squirrel (Petaurista philippensis) (ELLIOT) In Sitamata Wildlife Sanctuary, Rajasthan, India. Journal of Bombay Natural History Society. 107 (3):245.

[6] Borges, R. (1989). Resource heterogeneity and the foraging ecology of the Malabar Giant Squirrel (Ratufa indica). Ph.D.Thesis, Univ. of Miami, Florida.

[7] S. Babu, Kalaimani, A. (2014). New site record of Grizzled Giant Squirrel (Ratufa macroura) from Thiruvannamalai Forest Division, Eastern Ghats, Tamil Nadu, India. Journal of Threatened Taxa. 6(2): 5492-5493. 
[8] Coley, P.D. (1983). Herbivory and defensive characteristics of tree species in a lowland tropical forest. Ecological Monograph. 53:209-233.

[9] Ellerman, J.R. (1961). The fauna of India including Pakistan, Burma and Ceylon. Mamllia $\left(2^{\text {nd }}\right)$ vol. Rodentia. The zoological survey of India. Calcutta Rodentia. The Zoological Survey of India, Calcutta, 3:884.

[10] Gurnell, J. (1987). The Natural History of Squirrels. London: Christopher Helm.

[11] Dial, R. (2003). Energetic saving and the body size distributions of gliding mammals. Evolutionary Ecology Research. 5: 1151-1162.

[12] IUCN, (2013). Red List of Threatened Species Version 2013.1 downloaded on May 27, 2013. www.iucn.org/redlist.

[13] J. Joshua, Johnsingh, A.J.H. (1992). Status of endangered grizzled giant squirrel and its Habitats, in (K.J.S. Singh, eds.) Tropical ecosystems: Ecology and management, Willey Eastern Ltd, pp. 151-159. New Delhi.

[14] J. Joshua, Johnsingh, A.J.H. (1994). Impact of biotic disturbances on the habitat and population of the endangered Grizzled Giant Squirrel (Ratufa macroura) in South India. Biological Conservation. 68:29-34.

[15] Kawamichi, T. (1997). Seasonal changes in the diet of Japanese giant flying squirrels in relation to reproduction. Journal of Mammalogy. 78:204-212.

[16] Krishnamani, R. (1994). Diet composition of the Bonnet macaque (Macaca radiata) in a tropical dry evergreen forest of southern India. Tropical Biology. 2: 285-302.

[17] S. Karthikeyan, J.N. Prasad, Arun, B. (1992). Grizzled Giant Squirrel (Ratufa macroura) Thomas and Wroughton at Cauvery valley in Karnataka. Journal of Bombay Natural History Society. 89 (3):360-361.

[18] V.K. Koli, C. Bhatnagar, Sharma, S.K. (2013). Food habits of Indian giant flying squirrel (Petaurista philippensis Elliot) in tropical deciduous forest, Rajasthan, India. Mammal Study. 38: 251-259.

[19] C.C. Kuo, Lee, L. L. (2003). Food availability and food habits of Indian giant flying squirrels (Petaurista philippensis) in Taiwan. Journal of Mammalogy. 84:1330-1340.

[20] P.F. Lee, D.R. Progulske, Lin, Y. S. (1986). Ecological studies on two sympatric Petaurista species in Taiwan. Bulletin of the Institute of Zoology, Academia Sinica. 25:113-124.

[21] S. Molur, C. Srinivasulu, B. Srinivasulu, S. Walker, P.O. Nameer, Ravikumar L. (2005). Status of non-volant small mammals:Conservation Assessment and Management Plan (C.A.M.P) Workshop Report. Zoo outreach Organization/CBSG-South Asia, Coimbatore, India. Pp. 618.

[22] I. Muul, Lim boo liat, (1978). Comparative morphology, food habits and ecology of some Malaysian arboreal rodents. The ecology of arboreal folivores in (G.G. Montgomery, eds.) Smithsonian Institution.

[23] R. Nandini, Parthasarathy, N. (2008). Food habits of the Indian Giant flying Squirrel (Petaurista philippensis) in a rain forest fragment, Western Ghats. Journal of Mammalogy. 89: 1550-1556. 
[24] Prater, S.H. (1980). The book of Indian animals, Bombay Natural History society, Mumbai.

[25] Paulraj, S. (1991). Grizzled Giant Squirrel in its final throes of extinction process. Zoos print. $6(10): 1-2$.

[26] Ramachandran, K.K. (1988). Ecology and behaviour of Malabar Giant Squirrel (Ratufa indica maxima) (Schreber) 1788. Report of the Project Wild 04/83. Division of Wildlife Biology, Kerala Forest Research Institute, Peechi, Kerala.

[27] Ramachandran, K.K. (1992). Certain aspects of ecology and behaviour of Malabar Giant Squirrel (Ratufa indica) (Schreber). Ph.D. Thesis. Department of Zoology, University of Kerala.

[28] Reynolds, J.C. (1985). Autumn-winter energetic of Holarctic tree Squirrels: A review. $15: 137-150$.

[29] Tonkin, J.M. (1983). Activity patterns of red Squirrel (Sciurus vulgaris). Mammal Review. 13:99-111.

[30] J. Vanitharani, Kavitha, B. (2011). Analysis of tree Grizzled Giant Squirrel Interactions and guidelines for the maintenance of endangered Ratuf macroura, in Srivilliputhur Grizzled Giant Squirrel Wildlife Sanctuary. Small mammal Mail-bi-Annual Newsletter of CCINSA \& RISCINSA 3(2):9-13.

[31] L.A. Wauters, A.A. Swinnen, Dhondt, A.A. (1992). Activity budget and foraging behaviour of red squirrel (Sciurus vulgaris) in coniferous and deciduous habitats. Journal of Zoology. 227:71-86.

[32] L.A. Wauter, Dhondt, A.A. (1987). Activity budget and foraging behavior of red Squirrels (Sciurus vulgaris, Linnaeus, 1758) in a coniferous habitat. Z.saugetierk. 52:341353. 